\title{
Evaluation of Pediatric Patients Admitted to the Emergency Department with Head Trauma
}

\section{Acil Servise Kafa Travması Nedeniyle Başvuran Çocuk Hastaların Değerlendirilmesi}

\author{
DMetin Ocak', DSemih Akar² \\ 'Gazi State Hospital, Emergency Clinic Samsun, Turkey \\ ${ }^{2}$ Amasya University Faculty of Medicine, Department of Neurosurgery, Amasya, Turkey
}

\begin{abstract}
Aim: Head trauma is the most frequent reason for trauma related child deaths. Minor head traumas (MHT) form a considerable part of pediatric head traumas. Brain Computed Tomography (CT) is the gold standard for demonstrating intracranial pathologies in patients with head trauma. It is necessary to avoid having unnecessary CT scans in order to reduce the cost and the harms of radiation. We aim to assess the pediatric patients that applied to the emergency service with complaints of head trauma in the light of Prediction of Important Clinical Events (CHALICE) clinical decision-making rules.
\end{abstract}

Material and Method: 200 patients under 18 years old who applied to the emergency service with complaints of head trauma between 2016 and 2019 are included in this retrospective study.

Results: 200 patients in total were included in the study; of them, 128 are males and 72 are females. Of the patients, 3 have a Glaskow Coma Score (GCS) of 3-8, 2 have a GCS of 9-13, and the remaining 195 patients have a GCS of 14-15. Considering the symptoms, 35 patients had a headache, 28 patients had subcutaneous hematoma, and 26 patients had nausea-vomiting. The reason for trauma is motor vehicle accident for 99 patients and falling down from height for 95 patients. Four patients died. CHALICE $(+)$ rate was found $67.82 \%$ in the patients having a brain CT scan. $41.95 \%$ of asymptomatic patients had a brain CT scan.

Conclusion: Most of the patients participating in our study applied to the emergency service with minor head trauma. 32,18 percent of the patients who had brain CT were CHALICE (-) and $41.95 \%$ of the patients who had no symptoms showed us that unnecessary $\mathrm{CT}$ is performed at a high rate in pediatric MHT.

Keywords: Pediatric head trauma, CHALICE, computed brain tomography, defensive medicine, traumatic brain damage, minor head trauma

\section{Öz}

Amaç: Kafa travması travmaya bağlı çocuk ölümlerinin en sık sebebidir. Minör kafa travmaları (MKT) çocukluk kafa travmalarının önemli bir kısmını oluşturmaktadır. Beyin Bilgisayarlı Tomografisi (BT) kafa travması ile gelen hastalarda intrakraniyal patolojileri göstermek için altın standarttır. Ancak MKT'lerin küçük bir kısmında ciddi kafa içi hadise olduğu düşünüldüğünde maliyet ve radyasyonun zararlarını azaltmak için gereksiz tomografi çekmekten kaçınmak gerekir. Biz bu çalışmada acil servise kafa travması ile başvuran çocuk hastaları CHALICE klinik karar verme kuralları ışığında değerlendirmeyi amaçladık.

Gereç ve Yöntem: Bu retrospektif çalışmaya 2016-2019 tarihleri arasında 18 yaş altında acil servise kafa travması nedeniyle başvuran 200 çocuk hasta dahil edilmiştir.

Bulgular: Çalışmaya 128 erkek ve 72 kız olmak üzere toplam 200 hasta alınmıştır. Bunlardan 3'ünün GKS 3-8 arasında, 2'sinin GKS 9-13 arasında ve kalan 195 hastanın GKS 14-15 arasındadır. Semptomlara bakıldığında ise 35 hastada baş ağrısı, 28 hastada cilt altı hematom ve 26 hastada bulantı-kusma görülmüştür. Travma şekli 99 hastada araç içi trafik kazası ve 95 hastada yüksekten düşme şeklindedir. 39 hasta hastaneye yatırılarak tedavi edilmiştir. Exitus olan 4 hasta vardır. Beyin BT çekilenlerde CHALICE (+) oranı \%67,82 olarak tespit edilmiştir. Hiçbir semptomu olmayan hastaların \%41,95'ine beyin BT çekilmiştir.

Sonuç: Çalışmamıza katılan hastaların büyük çoğunluğu minor kafa travması ile acile servise başvurmuştur. Beyin BT çekilen hastaların \%32,18'i CHALICE (-) olması ve hiç bir semptomu olmayan hastaların \%41,95'ine beyin BT çekilmesi bize göstermiştir ki çocuk MKT'lerinde yüksek oranda gereksiz BT çekilmektedir.

Anahtar Kelimeler: Çocuk kafa travması, CHALICE, bilgisayarlı beyin tomografisi, defansif tıp, travmatik beyin hasarı, minör kafa travması 


\section{INTRODUCTION}

Trauma is the most significant reason for morbidity and mortality in children. Head trauma is the most frequent reason for trauma related child death at the rate of $80 \%{ }^{[1]}$ Childhood head traumas may lead to various clinical conditions ranging from mild to severe. However, most of the pediatric head traumas are mild. ${ }^{[2]}$ The most common reasons for pediatric head traumas are motor vehicle accidents, falling, assaults, bicycle accidents, and sports trauma. The most frequent reason for head trauma in babies under one year old is abuse. ${ }^{[3,4]}$

Minor head traumas (MHT) form a considerable part of pediatric head traumas. While incidence of intracranial pathologies in $\mathrm{MHT}$ varies between $3 \%$ and $5 \%$, the rate increases in younger children. ${ }^{[5]}$ Yet, such pathologies rarely require surgical intervention and proper management of such patients is still a controversial topic. ${ }^{[5,6]}$

Brain computed tomography (CT) is the gold standard for demonstrating intracranial pathologies in patients with head trauma. It enables early diagnosis and treatment of intracranial cases. However, it is a high-cost process for minor head traumas, in particular. ${ }^{[7]}$ On the other hand, it is indicated that exposure to ionizing radiation during computed tomography (CT) scanning increase the rates of brain tumor and leukemia in children. ${ }^{[8]}$ Considering that only $<1 \%$ of $\mathrm{MHT}$ is a severe intracranial case, ${ }^{[5]}$ one must be very careful in taking the risk of cost and radiation. Many decision-making rules were developed in making the decision for having a brain CT scan for such patients. The criteria of the Pediatric Emergency Care Applied Research Network (PECARN), Canadian Assessment of Tomography for Childhood Head Injury (CATCH), and Children's Head Injury Algorithm for the Prediction of Important Clinical Events (CHALICE) are the most frequently accepted clinical decision-making criteria that were developed for selective CT requests. ${ }^{[5]}$

In this study, we aim to assess the pediatric patients that applied to the emergency service with complaints of head trauma in the light of CHALICE clinical decision-making rules.

\section{MATERIAL AND METHOD}

200 patients under 18 years old who applied to the emergency service with complaints of head trauma between 2016 and 2019 are included in this retrospective monocentric study. Patient data were obtained retrospectively from patient files and hospital electronic information system. The ethics committee approval required for the study was obtained from the local ethics committee. (Ahi Evran University Clinical Research Ethics Committee's decision dated 22.05.2018 and numbered 2018$10 / 89)$

All patients under 18 years old who were diagnosed with head trauma in emergency service and for which brain CT scanning was performed and the patients under 18 years old who were kept under observation for 8 hours and above without brain CT scanning are included in the study. We reached the patients, who were kept under observation and then discharged, by phone whenever possible and obtained information on their later medical conditions. Those whom we failed to reach and obtain information are excluded from the study.

Demographic information, presenting symptoms, Glaskow Coma Score (GCS), Trauma mechanisms, CT images, hospitalization-discharge-death findings of all patients were recorded.

The patients with GCS $>13$ were evaluated as having a head trauma and 195 patients were evaluated in this category. The patients were also evaluated from the point of view of CHALICE clinical decision-making rules (Table 1) ${ }^{[9]}$

Table 1. CHALICE Clinical Decision Rule

History

1. Witnessed LOC $>5$ minutes

2. History of amnesia $>5$ minutes

3. Abnormal drowsiness

4. Over 3 discrete vomits

5. Physician's suspicion of nonaccidental injury

6. First ever seizure after injury

\section{Examination}

1. GCS $<14$ or $<15$ if under 1 year

2. Suspicion of penetrating or depressed skull injury or tense fontanelle

3. Sign of basil skull fracture

4. Positive focal neurological finding

5. Presence of bruise, swelling or laceration $>5 \mathrm{~cm}$ if $<1$ year old

\section{Mechanism}

1. Dangerous mechanism (MVA) $>40 \mathrm{mph}$

2. fall $>3$ meters

3. High speed projectile injury.

Statistical analyses were performed by using the program SPSS version 17.0. Conformity of variables to normal distribution was examined by histogram charts, and Kolmogorov-Smirnov test. Mean, standard deviation, and median values were used in presenting descriptive analyses. Categorical variables were compared by using Chi Square Test. While Mann Whitney U Test was used in evaluation of nonnormal (nonparametric) variables between two groups, Kruskal Wallis Test was used in evaluation of them among more than two groups. The conditions under which $p$-value is below 0.05 were valuated as statistically significant results.

\section{RESULTS}

A total of 200 patients were included in the study; of them, 128 are males and 72 are females. Of the patients, 3 have a GCS of 3-8, 2 have a GCS of 9-13, and the remaining 195 patients have a GCS of 14-15. Considering the symptoms, 35 patients had a headache, 28 patients had subcutaneous hematoma, and 26 patients had nausea-vomiting. Form of trauma is motor vehicle accident in 102 patients and falling down from height in 95 patients. 199 patients had blunt trauma and the remaining patient had a blunt and penetrating trauma. Spread of trauma is isolated head trauma in 105 patients and multisystem trauma in 95 patients. 39 patients were hospitalized. 4 patients died. Distribution of gender and clinical findings of the patients are given in Table $\mathbf{2}$. 
Mean age of the participants of this study is $8.66 \pm 5.47$ years. Mean length of hospital stay is $1.05 \pm 4.20$ days. Age and laboratory values of the patients are given in Table 3.

The patients were also evaluated by CHALICE clinical decisionmaking rules. CHALICE (+) rate was found $67.82 \%$ in patients with brain CT scan. 18 (15.25\%) of 118 CHALICE (+) patients having a brain CT scan was evaluated as CT (+); 100 (84.75\%) were evaluated as CT (-).

\begin{tabular}{|c|c|c|c|}
\hline & & $\mathbf{n}$ & $\%$ \\
\hline \multirow{2}{*}{ Gender } & Male & 128 & (64.50) \\
\hline & Female & 72 & (36.50) \\
\hline \multirow{3}{*}{ GCS } & $3-8$ & 3 & $(1.50)$ \\
\hline & $9-13$ & 2 & $(1.50)$ \\
\hline & $14-15$ & 195 & $(97.50)$ \\
\hline \multirow{6}{*}{ Symptom } & Headache & 35 & $(17.50)$ \\
\hline & Nausea-vomiting & 26 & $(13.50)$ \\
\hline & Changes in consciousness & 17 & $(8.50)$ \\
\hline & Subcutaneous hematoma & 28 & $(14.50)$ \\
\hline & No symptoms & 93 & $(46.50)$ \\
\hline & Cardiac arrest & 1 & $(.50)$ \\
\hline \multirow{5}{*}{$\begin{array}{l}\text { Form of } \\
\text { trauma }\end{array}$} & Falling from height & 95 & $(47.50)$ \\
\hline & Traffic accident-in-vehicle & 99 & $(49.50)$ \\
\hline & Injury by foreign body & 2 & $(1.50)$ \\
\hline & Battery-abuse & 1 & $(.50)$ \\
\hline & Traffic accident-extravehicular & 3 & $(1.50)$ \\
\hline \multirow{2}{*}{$\begin{array}{l}\text { Trauma } \\
\text { mechanism }\end{array}$} & Blunt & 199 & $(99.50)$ \\
\hline & Blunt + Penetrating & 1 & $(.50)$ \\
\hline \multirow{2}{*}{$\begin{array}{l}\text { Spread of } \\
\text { trauma }\end{array}$} & Isolated head trauma & 105 & $(52.50)$ \\
\hline & Multisystem trauma & 95 & $(47.50)$ \\
\hline \multirow{8}{*}{ Brain CT } & Bone fracture & 8 & $(4.50)$ \\
\hline & $\mathrm{SAH}$ & 4 & (2.50) \\
\hline & Subdural hemorrhage & 3 & $(1.50)$ \\
\hline & Contusio cerebri & 3 & $(1.50)$ \\
\hline & Normal Brain CT & 154 & $(77.50)$ \\
\hline & Brain CT not scanned & 26 & (13.50) \\
\hline & SAH + Subdural hemorrhage & 1 & $(.50)$ \\
\hline & Fracture in maxillofacial bones & 1 & $(.50)$ \\
\hline \multirow{2}{*}{ Treatment } & Outpatient treatment & 161 & $(80.50)$ \\
\hline & Hospitalization & 39 & $(19.50)$ \\
\hline \multirow{3}{*}{ Result } & Recovery & 195 & $(97.50)$ \\
\hline & Transfer & 1 & $(.50)$ \\
\hline & Dead & 4 & $(2.50)$ \\
\hline \multirow{2}{*}{ CT finding } & Present & 20 & $(10.00)$ \\
\hline & Absent & 180 & $(90.00)$ \\
\hline
\end{tabular}

Brain CT scanning of the patients were compared to the forms of trauma, symptoms, spread, treatment, results, and the rates of CT findings (Table 4). Accordingly, while the rate of falling down from height is higher in the patients with brain CT scan, the rate of traffic/ in-vehicle accidents as form of trauma is higher in the patients without brain CT scan. The rate of patients with brain CT scan who show the symptoms of headache and nausea-vomiting is higher compared to those without brain CT scan. The rate of isolated head trauma is higher in the patients with brain CT scan compared to those without brain CT scan. The rate of hospital stay is higher in the patients with brain CT scan compared to those without brain CT. No significant correlation was found between the presence of results and CT findings and the brain CT scans. In addition, it is remarkable that $41.95 \%$ of the asymptomatic patients had a brain CT scan.

Table 4. Comparison of Brain CT scanning of the patients to the rates of forms of trauma, symptoms, spread of trauma, treatment, result, and CT finding

\begin{tabular}{|c|c|c|c|c|c|c|}
\hline & \multicolumn{4}{|c|}{ Brain CT } & \multirow{3}{*}{ P* } \\
\hline & & \multicolumn{2}{|c|}{ Scanned } & \multicolumn{2}{|c|}{ Not Scanned } & \\
\hline & & $\mathbf{n}$ & $\%$ & $\mathbf{n}$ & $\%$ & \\
\hline \multirow{5}{*}{$\begin{array}{l}\text { Form of } \\
\text { trauma }\end{array}$} & Falling from height & 90 & $(51.72)$ & 5 & (19.23) & \multirow{5}{*}{0.019} \\
\hline & Traffic accident-in-vehicle & 78 & $(44.83)$ & 21 & $(80.77)$ & \\
\hline & Injury by foreign body & 2 & $(1.15)$ & 0 & $(.50)$ & \\
\hline & Battery-abuse & 1 & $(.57)$ & 0 & $(.50)$ & \\
\hline & $\begin{array}{l}\text { Traffic accident- } \\
\text { extravehicular }\end{array}$ & 3 & $(1.72)$ & 0 & $(.50)$ & \\
\hline \multirow{6}{*}{ Symptom } & Headache & 31 & $(17.82)$ & 4 & (15.38) & \multirow{6}{*}{0.001} \\
\hline & Nausea-vomiting & 25 & (14.37) & 1 & $(3.85)$ & \\
\hline & Changes in consciousness & 17 & $(9.77)$ & 0 & $(.50)$ & \\
\hline & Subcutaneous hematoma & 28 & (16.09) & 0 & $(.50)$ & \\
\hline & No symptoms & 73 & (41.95) & 20 & (76.92) & \\
\hline & Cardiac arrest & 0 & $(.50)$ & 1 & $(3.85)$ & \\
\hline \multirow{2}{*}{$\begin{array}{l}\text { Spread of } \\
\text { trauma }\end{array}$} & Isolated head trauma & 98 & (56.32) & 7 & $(26.92)$ & \multirow{2}{*}{0.005} \\
\hline & Multisystem trauma & 76 & (43.68) & 19 & (73.08) & \\
\hline \multirow{2}{*}{ Treatment } & Outpatient treatment & 136 & (78.16) & 25 & (96.15) & \multirow{2}{*}{0.031} \\
\hline & Hospitalization & 38 & (21.84) & 1 & $(3.85)$ & \\
\hline \multirow{3}{*}{ Result } & Recovery & 170 & $(97.70)$ & 25 & (96.15) & \multirow{3}{*}{0.717} \\
\hline & Transfer & 1 & $(.57)$ & 0 & $(.50)$ & \\
\hline & Dead & 3 & $(1.72)$ & 1 & (3.85) & \\
\hline \multirow{2}{*}{ CT finding } & Present & 20 & (11.49) & 0 & $(.50)$ & \multirow{2}{*}{0.068} \\
\hline & Absent & 154 & $(88.51)$ & 26 & $(100.00)$ & \\
\hline
\end{tabular}

Table 3. Age and laboratory value of the patients

\begin{tabular}{|c|c|c|c|c|c|}
\hline & Mean & \pm s.d. & Median & Min. & Max. \\
\hline Age (years) & 8.66 & \pm 5.47 & 8.50 & .50 & 17.50 \\
\hline $\mathrm{WBC}(/ \mu \mathrm{L})$ & 11336.62 & \pm 4514.53 & 10125.50 & 4330.00 & 27610.00 \\
\hline Neutrophile $(/ \mu \mathrm{L})$ & 5913.20 & \pm 3638.18 & 4935.50 & 810.00 & 23940.00 \\
\hline 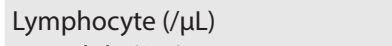 & 4168.25 & \pm 2338.59 & 3620.00 & 920.00 & 14550.00 \\
\hline 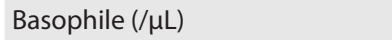 & 34.50 & \pm 41.38 & 10.00 & .50 & 300.00 \\
\hline Eosinophile $(/ \mu \mathrm{L})$ & 158.40 & \pm 299.45 & 44.50 & .50 & 1990.00 \\
\hline $\mathrm{HGB}(\mathrm{g} / \mathrm{dL})$ & 12.68 & \pm 1.59 & 12.70 & 5.50 & 16.80 \\
\hline HTC (\%) & 37.59 & \pm 4.57 & 37.60 & 14.50 & 48.40 \\
\hline $\mathrm{PLT}(/ \mu \mathrm{L})$ & 309530.00 & \pm 92740.95 & 298500.00 & 32000.00 & 526000.00 \\
\hline $\mathrm{NA}(\mathrm{mmol} / \mathrm{L})$ & 138.51 & \pm 3.03 & 138.50 & 127.50 & 153.50 \\
\hline $\mathrm{K}(\mathrm{mmol} / \mathrm{L})$ & 4.13 & \pm .45 & 4.10 & 3.50 & 5.50 \\
\hline $\mathrm{Cl}(\mathrm{mmol} / \mathrm{L})$ & 103.07 & \pm 3.59 & 103.50 & 94.50 & 130.00 \\
\hline $\mathrm{CRP}(\mathrm{mg} / \mathrm{L})$ & 3.02 & \pm 8.09 & .31 & .50 & 73.50 \\
\hline Length of Hospitalization (days) & 1.05 & \pm 4.20 & .50 & .50 & 48.50 \\
\hline
\end{tabular}


The correlation among GCS and form of trauma, symptom, trauma mechanism, spread, brain $\mathrm{CT}$, treatment, and result were examined. Accordingly, we found that there is a significant correlation among GCS and symptom, brain CT, treatment, and result ( $p<0.001$ for all of them). While the rate of headache is higher in the patients with GCS of 14-15, the rate of changes in consciousness is higher in those with GCS of 3-8 and GCS of 9-13. While the rate of bone fracture is higher in the patients with GCS of 14-15; the rate of SAH is higher in those with GCS of 3-8; the rate of subdural hemorrhage is higher in those with GCS of 9-13. The rate of hospital stay is lower in the patients with GCS of 14-15 compared to those with GCS of 3-8 and GCS of 9-13. Mortality rate is higher in the patients with GCS of 3-8 compared to those with GCS of 9-13 and GCS of 14-15. GCS is 14-15 in the patients with changes in consciousness compared to those with other symptoms. The rate of bone fracture is higher in the patients with Subcutaneous Hematoma compared to those with NauseaVomiting and Changes in Consciousness. The rate of hospital stay is higher in the patients with changes in consciousness compared to those with Nausea-Vomiting and Subcutaneous
Hematoma. Death rate is lower in the patients with NauseaVomiting compared to those with Changes in Consciousness and Cardiac Arrest $(\mathrm{p}<0.001)$.

The rate of isolated head trauma as spread of trauma is higher in the patients with the form of trauma due to falling from height as compared to those with the form of trauma due to in-vehicle traffic accident and extravehicular traffic accident $(p<0.001)$. The rate of brain CT bone fracture is higher in the patients with the form of trauma due to falling from height compared to those with the form of trauma due to in-vehicle traffic accident $(p=0.01)$. Distribution of GCS, symptoms, form of trauma, trauma mechanism, spread of trauma, treatment, and result rates of the patients by brain CT is given in Table 5 .

When brain CT findings of the patients are sorted out as present/absent, the number of patients with GCS of 3-8 and GCS of 9-13 in CT findings are higher than the patients without CT findings. The rate of changes in consciousness is higher in the patients with $\mathrm{CT}$ findings compared to those without $\mathrm{CT}$ findings ( $p<0.001$ for all of them).

Table 5. Comparison of Clinical Findings and Trauma Characteristics of the Patients to Brain C

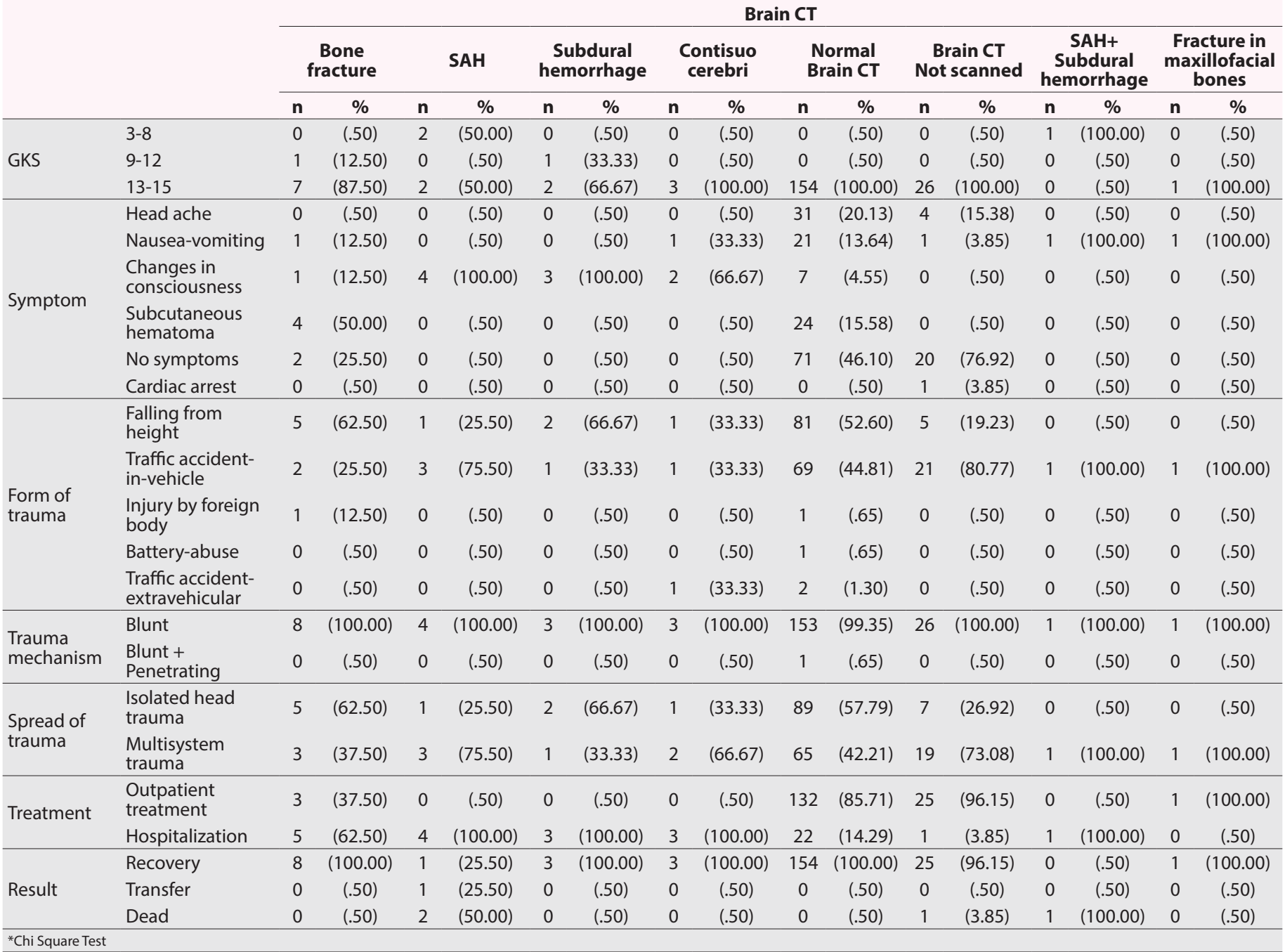




\section{DISCUSSION}

We found that $32.18 \%$ of the patients in the study had a brain CT scan although they turned out CHALICE (-) and $15.25 \%$ of CHALICE (+) patients turned out CT (+). 154 (88.5\%) out of 174 patients in total for which tomography scanning was performed were evaluated as normal. In addition, it is remarkable that brain CT scan was performed for $41.95 \%$ of the asymptomatic patients. The National Cancer Institute and the Food and Drug Administration have recommended a decrease in radiation exposure by eliminating unnecessary CT scans, with special emphasis on the pediatric population. ${ }^{[10]}$ The findings make us think that brain CT scan is not reasonable in examination of pediatric head traumas considering the side effects of radiation and the cost. The plans required to minimize unnecessary $\mathrm{CT}$ scans in children must be made without delay.

The need for reduce unnecessary CT scans while minimizing the risk of missing the symptoms of clinically significant traumatic brain injury (TBI) led to development of clinical estimate rules designed to guide the clinicians in CT decisionmaking process. ${ }^{[11]}$ The 3 most frequently used decisionmaking rules (PECARN, CATCH, and CHALICE) are hard to compare with each other as they have different objectives and target population. For example, CHALICE includes all children with head trauma; PECARN includes the children with head trauma and GCS of 14-15; CATCH includes the children with head trauma and GCS of $13-15 .{ }^{[1]]}$ The reason for using CHALICE decision-making rules in this study is the fact that the study contains patients from all groups. Clinical estimate rule for CHALICE head trauma was derived for evaluation of head traumas of all degrees in a prospective cohort analysis consisting of 22,722 children that applied to emergency service in The United Kingdom between 2000 and 2002. ${ }^{[12]}$ It was reported that this decision-making rule indicates traumatic brain damage with of $98.6 \%$ sensitivity and $86.9 \%$ specificity. ${ }^{[1]}$

In this study; It is noteworthy that $32.18 \%$ of CHALICE (-) patients had CT performed, $88.5 \%$ of patients underwent CT scan had normal results, and $41.95 \%$ of asymptomatic patients had CT scans. This situation made us think of clinicians perform unnecessary CT scans for pediatric head traumas with a defensive medicine approach without utilizing any of the clinical decision-making rules.

In defensive medicine, a physician avoids unnecessary use of medical practices for diagnosis and treatment and the practices that are highly likely to result in a malpractice case by behaving overprotectively or reservedly in order not to encounter any criminal or legal action, pay damage or increase the premiums on insurance policy. ${ }^{[13]}$ In a compilation published in 2019, the reasons for defensive medicine are specified as physician-patient communication, medical error and malpractice cases, the effect of media, lack in professional experience, violence, healthcare system, patient complaints, patient density, and the desire to become a perfect physician. ${ }^{[14]}$ We think that it is very important to minimize the reasons that push the physicians to adopt defensive medicine approach as well as the trainings for physicians in order to reduce unnecessary CT scans for pediatric patients with head trauma.

GCS is one of the oldest and most common scoring systems that are used for evaluation of the patients with head trauma. Besides, GCS is frequently used in separating the patients with head trauma into subgroups, diagnosis and treatment methods, and repetitive evaluation of patients. ${ }^{[15]}$ It was reported in many previous studies that low GCS values and changes in consciousness are related to mortality due to brain damage and head trauma. ${ }^{[16-18]}$ In addition, GCS and changes in consciousness are common physical examination findings that indicate a high risk in PECARN, $\mathrm{CATCH}$, and CHALICE which are the most frequently used decision-making rules for MHTs in children..$^{[9]}$ This study indicates in line with the literature that GCS and changes in consciousness are related to clinical condition, brain damage, intracranial case, hospital stay and mortality of the patients. A previous study on 29,433 pediatric patients with head trauma reported that $63.7 \%$ of the patients are males and $95.4 \%$ have a GCS of 15 . In addition, $70.1 \%$ of the patients in this study applied to the hospital with complaints of falling. The most frequent presenting symptoms were reported to be headache and vomiting. Only $<1 \%$ of the patients needed surgical intervention. ${ }^{[9]}$ The data in the literature are also similar. ${ }^{[19]}$ In this study, $64 \%$ of the patients are males and $36 \%$ are females. $97.5 \%$ of the patients have a GCS of $>13$. The patients applied to the hospital with complaints of head ache at the rate of $17.5 \%$ and nausea-vomiting at the rate of $13 \% .49 .5 \%$ of the patients applied to the hospital due to motor vehicle accident and $47.5 \%$ applied due to falling from height. CT findings were found in $10 \%$ of the patients. Only 4 patients died. The data in this study are consistent with the literature.

\section{Limitations}

The study is limited to being monocentric, retrospective, and the limited number of patients. We think of supporting the study findings with later prospective and multicentric studies with more patients in the future. Besides, studying the reasons that push physicians to defensive approach in making the decision in performing tomography scanning for pediatric head traumas may be beneficial in developing approaches to reduce the rate of unnecessary tomography scans in the future.

\section{CONCLUSION}

The fact that there are lots of CHALICE(-) patients for which CT scanning is performed in this study, results of a great majority of the patients for which CT scanning is performed are normal and CT scanning is performed for $41.95 \%$ of the asymptomatic patients make us think that physicians don't utilize any of the clinical decision-making rules due to their 
defensive medicine approach. We think that it is important to investigate and minimize the reasons that push the physicians to adopt defensive medicine approach as well as the trainings for physicians in order to reduce unnecessary tomography scans for MHTs in pediatric patients.

\section{ETHICAL DECLARATIONS}

Ethics Committee Approval: Ahi Evran University Clinical Research Ethics Committee's decision dated 22.05.2018 and numbered 2018-10 / 89

Informed Consent: Because the study was designed retrospectively, no written informed consent form was obtained from patients.

Referee Evaluation Process: Externally peer-reviewed.

Conflict of Interest Statement: The author(s) declared no potential conflicts of interest with respect to the research, authorship, and/or publication of this article.

Financial Disclosure: The authors declared that this study has received no financial support.

Author Contributions: All of the authors declare that they have all participated in the design, execution, and analysis of the paper, and that they have approved the final version.

\section{REFERENCES}

1. Isık HS, Gökyar A, Yıldız Ö, Bostancı U, Ozdemir C. Pediatric head injuries, retrospective analysis of 851 patients: an epidemiological study.[in Turkish] Ulus Travma Acil Cerrahi Derg 2011;17(2):166-72.

2. Yasar S, Kırık A, Durmaz MO. Pediatric head traumas: A different perspective. Ulus Travma Acil Cerrahi Derg 2020;26:765-8

3. Duhaime AC, Christian CW, Rorke LB, Zimmerman RA. Nonaccidental head injury in infants--the "shaken-baby syndrome". N Engl J Med 1998;338:1822-9.

4. Greenberg JK, Jeffe DB, Carpenter CR, et al. North American survey on the post-neuroimaging management of children with mild head injuries. J Neurosurg Pediatr 2018;23:227-35.

5. Gizli G, Durak VA, Koksal O. The comparison of PECARN, CATCH, AND CHALICE criteria in children under the age of 18 years with minor head trauma in emergency department. Hong Kong J Emerg Med 2020:1-7

6. Hebb MO, Clarke DB, Tallon JM. Development of a provincial guideline for the acute assessment and management of adult and pediatric patients with head injuries. Can J Surg 2007; 50: 187-94.

7. Stiell IG, Wells GA, Vandemheen K, et al. Variation in ED use of computed tomography for patients with minor head injury. Ann Emerg Med 1997;30(1):14-22.

8. Brenner DJ. Estimating cancer risks from pediatric CT: going from the qualitative to the quantitative. Pediatr Radiol 2002;32(4):228-31.

9. McGraw M, Way T. Comparison of PECARN, CATCH, and CHALICE clinical decision rules for pediatric head injury in the emergency department. CJEM. 2019;21(1): 120-4

10. Food and Drug Administration. FDA Public Health Notification. Pediatr Radiol 2002;32:314-6

11. Nigrovic LE and Kuppermann N. Children with minor blunt head trauma presenting to the emergency department. Pediatrics. 2019;144(6): e201914

12. Dunning J, Daly JP, Lomas J-PP, Lecky F, Batchelor J, Mackway-Jones K. Children's Head Injury Algorithm for the Prediction of Important Clinical Events Study Group. Derivation of the children's head injury algorithm for the prediction of important clinical events decision rule for head injury in children. Arch Dis Child 2006;91(11):885-91
13. Kessler D, McClellan M. Do doctors practice defensive medicine?. The Quarterly Journal of Economics 1996; 111(2): 353-90.

14. Yeşiltaş A, Erdem R. A Revıew On Defensıve Medical Applicatıons. Suleyman Demirel University Visionary J 2019;10 (23):137-50

15. Bozan Ö, Aksel G, Kahraman HA, Giritli Ö, Eroğlu SE. Comparison of PECARN and CATCH clinical decision rules in children with minor blunt head trauma. Eur J Trauma Emerg Surg 2019;45:849-55

16. Dunning J, Daly JP, Lomas JP, Lecky F, Batchelor J, Mackway- Jones K. Children's head injury algorithm for the prediction of important clinical events study group. Derivation of the children's head injury algorithm for the prediction of important clinical events decision rule for head injury in children. Arch Dis Child 2006;91(11):885-91.

17. Palchak MJ, Holmes JF, Vance CW, et al. Does an isolated history of loss of consciousness or amnesia predict brain injuries in children after blunt head trauma? Pediatrics. 2004;113(6):e507-13.

18. Atabaki SM, Stiell IG, Bazarian JJ, et al. A clinical decision rule for cranial computed tomography in minor pediatric head trauma. Arch Pediatr Adolesc Med 2008;162(5):439-45.

19. Atabaki SM. Pediatric Head Injury. Pediatr Rev 2007;28;215-25. 